\title{
Cytomorphological Features of Medullary Thyroid Carcinoma: An Analysis based on 41 Ultrasound- guided Fine-needle Aspiration Specimens
}

\author{
${ }^{1}$ Sushila Jaiswal, ${ }^{2}$ Raghunandan Prasad, ${ }^{3}$ Farhana Siddiqui, ${ }^{4}$ Hira Lal, ${ }^{5}$ Neha Nigam, ${ }^{6}$ Azfar Neyaz \\ ${ }^{7}$ Sabaretnam Mayilvaganan, ${ }^{8}$ Gyan Chand, ${ }^{9}$ Amit Agarwal
}

\section{ABSTRACT}

Introduction: Medullary thyroid carcinoma (MTC) is a malignant tumor of thyroid gland showing parafollicular or C-cell differentiation.

Aims and objectives: The current study was undertaken to evaluate safety of ultrasound-guided thyroid fine-needle aspiration cytology (FNAC) and to assess cytomorphological features of MTC in FNA specimens from 28 patients.

Materials and methods: The study was performed by retrospectively reviewing the clinical and pathological records of MTC cases managed at our institute.

Results: The patients included 18 males and 10 females with a mean age of 45.3 years; 24 specimens were taken from thyroid, 15 from cervical lymph nodes and one each from liver space occupying lesion and chest wall nodule. There was no complication noted during ultrasound-guided FNAC in these patients. The smears had variable cellularity in the form of moderate cellularity in $63 \%$ of specimens and low cellularity in $15 \%$ of specimens. Cell arrangements were solid cohesive in $39 \%$ of cases and microfollicular clusters in $36 \%$ of cases. The frequent microfollicles in two specimens prompted the differential of follicular carcinoma. Dispersed population was noted in $90 \%$ of specimens. Binucleated and multinucleated cells were seen in 58 and $53 \%$ specimens respectively. Only spindle cell morphology was noted in $2 \%$ of specimens. Central

\footnotetext{
${ }^{1,4,8}$ Additional Professor, ${ }^{2,5,7}$ Assistant Professor, ${ }^{3}$ Demonstrator ${ }^{6}$ Senior Resident, ${ }^{9}$ Professor

${ }^{1}$ Department of Pathology, Sanjay Gandhi Postgraduate Institute of Medical Sciences, Lucknow, Uttar Pradesh, India

${ }^{2,4}$ Department of Radiodiagnosis, Sanjay Gandhi Postgraduate Institute of Medical Sciences, Lucknow, Uttar Pradesh, India

${ }^{3}$ Department of Pathology, FH Medical College and Hospital Agra, Uttar Pradesh, India

${ }^{5}$ Department of Pathology, King George's Medical University Lucknow, Uttar Pradesh, India

${ }^{6}$ Department of Pathology, Dr. Ram Manohar Lohia Institute of Medical Sciences, Lucknow, Uttar Pradesh, India

${ }^{7-9}$ Department of Endocrine Surgery, Sanjay Gandhi Postgraduate Institute of Medical Sciences, Lucknow, Uttar Pradesh, India

Corresponding Author: Raghunandan Prasad, Assistant Professor, Department of Radiodiagnosis, Sanjay Gandhi Postgraduate Institute of Medical Sciences, Lucknow, Uttar Pradesh, India, e-mail: coolraghu2001@gmail.com
}

to eccentric nuclei were present in $39 \%$ of specimens, while $13 \%$ of specimens showed mainly eccentric nuclei. In all the specimens, neuroendocrine type of salt and pepper-like morphology was present which is best seen with Papanicolaou (Pap) stain. Similarly, cytoplasm showed granules in $78 \%$ and fine vacuoles in $29 \%$ of specimens. Amyloid appreciated as flecks or aggregates of amorphous pink or gray color was seen in $37 \%$ of specimens. No mitosis was noted in any specimen, while necrosis was seen in only in one specimen.

Conclusion: Ultrasound-guided FNAC is a fairly accurate, relatively safe, rapid, and simple tool for preoperative diagnosis of thyroid malignancies. Although the cytological features of MTC are well described, different patterns may pose a diagnostic difficulty.

Keywords: Fine-needle aspiration cytology, Fine-needle aspiration cytology thyroid, Medullary thyroid carcinoma, Thyroid carcinoma.

How to cite this article: Jaiswal S, Prasad R, Siddiqui F, Lal H, Nigam N, Neyaz A, Mayilvaganan S, Chand G, Agarwal A. Cytomorphological Features of Medullary Thyroid Carcinoma: An Analysis based on 41 Ultrasound-guided Fine-needle Aspiration Specimens. World J Endoc Surg 2018;10(2):108-118.

Source of support: Nil

Conflict of interest: None

\section{INTRODUCTION}

Medullary thyroid carcinoma is a malignant epithelial tumor showing parafollicular cell differentiation. It has also been described as solid carcinoma, hyaline carcinoma, C-cell carcinoma, and neuroendocrine carcinoma of thyroid. The MTC was first described by Horn, ${ }^{1}$ but was named MTC by Hazard et $\mathrm{al}^{2}$ and he also recognized the characteristic amyloid stroma. Most of the patients present with a thyroid mass, pain, dysphagia, hoarseness, diarrhea, or cervical lymphadenopathy. Rare presentations include Cushing syndrome or unexplained elevated level of serum carcinoembryonic antigen (CEA). It can also occur as a component of multiple endocrine neoplasia (MEN) syndromes apart from sporadic form. Therefore, it is important to rule out the possibility of these syndromes including pheochromocytoma in cases of MTC preoperatively. Following diagnosis of MTC by simple and safe technique of ultrasound-guided/nonguided FNA, the patient and patient's family members 
must be screened for the possible MEN syndrome and pheochromocytoma by the appropriate investigation. The current study was undertaken to study the safety of ultrasound-guided thyroid FNAC and to assess cytomorphological features of MTC in 41 specimens of ultrasound-guided FNA specimens from 28 patients.

\section{MATERIALS AND METHODS}

Forty-one specimens of ultrasound-guided FNA from 28 patients of MTC, who underwent cytological examination over a period of last 90 months, were retrieved from the Hospital information system (HIS). Among these patients, one patient was a known case of MTC with recurrent swelling, in whom ultrasound-guided FNAC was taken from recurrent swelling; 24 FNA specimens were taken from thyroid, 15 from cervical lymph node, and one each from liver space occupying lesion and chest wall nodule. The FNA was performed without anesthesia and under ultrasound guidance in all cases. The FNA smears were fixed in 95\% alcohol, were stained with Pap and hematoxylin and eosin stain and, if needed, with Congo red stain, while air-dried smears were stained with May Grunwald Giemsa (MGG) stain. The clinical data, including patient age and gender, clinical presentation, investigations, and operative details were recorded from the HIS.
Cytomorphological features in all the specimens were reviewed for cellularity (low, moderate, and high) smear pattern (solid or cohesive, loosely cohesive or dispersed pattern, microfollicular, trabecular, and papillaroid), type of cell (round to oval, spindle or mixed), nuclear features [pleomorphism, location, i.e., nuclei central or eccentric (plasmacytoid), occasional presence of intranuclear cytoplasmic inclusions, binucleation multinucleation, nuclear overlapping, grooving, and inclusions], bizarre cell cytoplasmic features (color, granules, vacuoles), amyloid, necrosis, and mitosis.

\section{RESULTS}

\section{Cases and Specimen Details}

A total of 41 specimens from 28 patients (Table 1) comprising of 18 males and 10 females respectively (M:F 1.8:1), were included in the study. The age ranged from 9 to 75 years (mean 45.3 years). Table 2 summarizes the cytological features of all the specimens. A total of 41 specimens including 24 thyroid, 15 cervical lymph node specimens, and one case each of liver space occupying lesion and chest wall nodule were available for the study. There was no complication reported during ultrasoundguided FNAC in these patients.

Table 1: Summary of cytological and histological correlation of 41 specimens of MTC (28 cases)

\begin{tabular}{|c|c|c|c|c|c|c|c|}
\hline $\begin{array}{l}\text { Case } \\
\text { no. }\end{array}$ & Age & Sex & $\begin{array}{l}\text { Specimen } \\
\text { no. }\end{array}$ & Site of FNAC & Cytological diagnosis & $\begin{array}{l}\text { Histopathological } \\
\text { diagnosis }\end{array}$ & Remarks \\
\hline 1 & 54 & $\mathrm{M}$ & 1 & Thyroid & S/O PDC & MTC & \\
\hline & & & 2 & Cervical lymph node & S/O PDC & Metastatic MTC & \\
\hline
\end{tabular}

$263 \quad \mathrm{~F} \quad 4$

Liver SOL

Cervical lymph node

C/W MTC

S/O Metastatic MTC, paraganglioma, or metastatic carcinoma

$\begin{array}{llllll} & & 5 & \begin{array}{l}\text { Cervical lymph node } \\ \text { (Recurrent) }\end{array} & \text { Metastatic MTC } \\ \text { Cervical lymph node } & \text { C/W MTC } \\ \text { (recurrent) } & \text { M } & 6 & \end{array}$

Thyroid
Cervical lymph node
Thyroid
Thyroid
Thyroid

$\begin{array}{llll}4 & 52 & \text { M } & 7 \\ 5 & 45 & \text { F } & 9 \\ 6 & 72 & \text { F } & 10 \\ 7 & 49 & \text { M } & 11\end{array}$

Presented as left cervical lymph node and thyroid enlargement. After FNAC from cervical lymph node only, operated for thyroid mass

Metastatic MTC

Metastatic MTC

Diagnosed case of PDC on FNA Cx lymph node (reported outside) Preoperative S-calcitonin level $15619 \mathrm{pg} / \mathrm{mL}$ Cx LN FNAC done in this institute after thyroidectomy

$\begin{array}{ll}\text { S/O MTC } & \text { MTC } \\ \text { S/O metastatic MTC } & \text { Metastatic MTC } \\ \text { S/O MTC } & \text { MTC } \\ \text { S/O MTC } & \text { MTC } \\ \text { S/O follicular neoplasm. } & \text { MTC } \\ \begin{array}{ll}\text { However, P/O MTC can't } \\ \text { be ruled out }\end{array} & \end{array}$




\begin{tabular}{|c|c|c|c|c|c|c|c|}
\hline $\begin{array}{l}\text { Case } \\
\text { no. }\end{array}$ & Age & Sex & $\begin{array}{l}\text { Specimen } \\
\text { no. }\end{array}$ & Site of FNAC & Cytological diagnosis & $\begin{array}{l}\text { Histopathological } \\
\text { diagnosis }\end{array}$ & Remarks \\
\hline & & & 12 & $\begin{array}{l}\text { Cervical lymph node } \\
\text { (recurrent) }\end{array}$ & $\begin{array}{l}\text { Negative for malignant } \\
\text { cells. On review positive } \\
\text { for malignant cells }\end{array}$ & Metastatic MTC & \\
\hline 8 & 49 & M & 13 & Thyroid & S/O MTC & MTC & \\
\hline \multirow[t]{2}{*}{9} & 36 & M & 14 & $\begin{array}{l}\text { Cervical lymph node } \\
\text { (guided) }\end{array}$ & S/O neoplasm (?MTC) & MTC & \\
\hline & & & 15 & Thyroid (guided) & S/O neoplasm (?MTC) & MTC & \\
\hline 10 & 54 & $\mathrm{~F}$ & 16 & Thyroid & S/O MTC & MTC & \\
\hline \multirow[t]{3}{*}{11} & 37 & M & 17 & Thyroid & C/W MTC & MTC & \\
\hline & & & 18 & $\begin{array}{l}\text { Cervical lymph node } \\
\text { (recurrent) }\end{array}$ & C/W Metastatic MTC & Metastatic MTC & \\
\hline & & & 19 & $\begin{array}{l}\text { Cervical lymph node } \\
\text { (recurrent) }\end{array}$ & $\mathrm{C} / \mathrm{W}$ metastatic MTC & Metastatic MTC & \\
\hline 12 & 40 & $\mathrm{~F}$ & 20 & Thyroid & S/O neoplasm. Adv HPE & MTC & \\
\hline \multirow[t]{2}{*}{13} & 47 & M & 21 & Thyroid & S/O MTC. Adv HPE & MTC & \\
\hline & & & 22 & Cervical lymph node & S/O MTC. Adv HPE & Metastatic MTC & \\
\hline 14 & 44 & $\mathrm{~F}$ & 23 & Thyroid & P/O MTC. Adv HPE & MTC & $\begin{array}{l}\text { On FNA aspirate } \\
\text { Congophilic apple green } \\
\text { birefringence under } \\
\text { polarized microscope }\end{array}$ \\
\hline \multirow[t]{2}{*}{15} & 43 & M & 24 & $\begin{array}{l}\text { Cervical lymph node } \\
\text { (recurrent) }\end{array}$ & $\begin{array}{l}\text { S/O metastatic MTC. } \\
\text { Adv HPE }\end{array}$ & Metastatic MTC & $\begin{array}{l}\text { Thyroidectomy was done } \\
\text { without FNAC of thyroid }\end{array}$ \\
\hline & & & 25 & Chest wall nodule & Few atypical cells & Not done & \\
\hline \multirow[t]{3}{*}{16} & 75 & M & 26 & Cervical lymph node & S/O MTC. Adv HPE & Metastatic MTC & \\
\hline & & & 27 & Thyroid & $\begin{array}{l}\text { S/O MTC. Adv HPE } \\
2 \mathrm{HPE}\end{array}$ & MTC & \\
\hline & & & 28 & $\begin{array}{l}\text { Cervical lymph node } \\
\text { (recurrence) }\end{array}$ & $\begin{array}{l}\text { S/O MTC. Adv HPE } \\
2 \mathrm{HPE}\end{array}$ & Metastatic MTC & \\
\hline 17 & 38 & M & 29 & $\begin{array}{l}\text { Substernal lymph } \\
\text { node (recurrence) }\end{array}$ & $\begin{array}{l}\mathrm{C} / \mathrm{W} \text { metastatic } \\
\text { carcinoma }\end{array}$ & Metastatic MTC & $\begin{array}{l}\text { Known diagnosed patient } \\
\text { of MTC from outside on } \\
\text { follow-up }\end{array}$ \\
\hline 18 & 56 & $\mathrm{~F}$ & 30 & Thyroid & $\begin{array}{l}\text { Positive for atypical cells } \\
\text { P/o MTC or PDC }\end{array}$ & MTC & \\
\hline 19 & 38 & M & 31 & Thyroid & $\begin{array}{l}\text { (MTC) review slide } \\
\text { (MTC) }\end{array}$ & Not done & $\begin{array}{l}\text { On FNA Congophilic } \\
\text { deposit shows apple } \\
\text { green birefringence under } \\
\text { polarized light. After FNAC } \\
\text { lost to follow-up }\end{array}$ \\
\hline 20 & 14 & $\mathrm{~F}$ & 32 & Thyroid & C/W MTC & $\begin{array}{l}\text { Histology not done } \\
\text { Refused surgery }\end{array}$ & $\begin{array}{l}\text { Daughter of a known case } \\
\text { of MEN } 2 \text { Syndrome. (case } \\
21 \text { ) C/W MEN } 2 A \text {. Has no } \\
\text { symptoms, was detected to } \\
\text { have codon } 634 \text { mutation } \\
\text { on genetic screening }\end{array}$ \\
\hline 21 & 36 & M & 33 & Thyroid & C/W MTC & MTC & Father (index case) \\
\hline 22 & 9 & M & 34 & Thyroid & C/W MTC & MTC & $\begin{array}{l}\text { Son of known MEN 2A } \\
\text { (case 21). RET codon } 634 \\
\text { mutation present }\end{array}$ \\
\hline 23 & 11 & $\mathrm{~F}$ & 35 & Thyroid & C/W MTC & MTC & $\begin{array}{l}\text { Daughter of MEN } 2 A \text { (case } \\
21 \text { ) positive for RET codon } \\
634 \text { mutation (on screening } \\
\text { genetic analysis was done) }\end{array}$ \\
\hline \multirow[t]{2}{*}{24} & 59 & M & 36 & Thyroid & C/W MTC & MTC & \\
\hline & & & 37 & Cervical lymph node & $\mathrm{C} / \mathrm{W}$ metastatic MTC & Metastatic MTC & \\
\hline 25 & 48 & M & 38 & Thyroid & C/W MTC & MTC & \\
\hline 26 & 62 & M & 39 & Thyroid & C/W MTC & MTC & \\
\hline 27 & 45 & M & 40 & Thyroid & C/W MTC & MTC & \\
\hline 28 & 28 & $\mathrm{~F}$ & 41 & Thyroid & C/W follicular neoplasm & MTC & \\
\hline
\end{tabular}

SOL: Space-occupying lesion; S/O: Suggestive of; P/O: Possibility of; C/W: Consistent with; Adv: Advise; HPE: Histopathological examination; Cx: cervical lymph node; ?: Suspicious 


\begin{tabular}{|c|c|c|}
\hline Cytomorphological features & $\begin{array}{l}\text { No. of } \\
\text { specimens }\end{array}$ & $\%$ \\
\hline \multicolumn{3}{|l|}{ Cellularity } \\
\hline High & 9 & 21.95 \\
\hline Moderate & 26 & 63.41 \\
\hline Low & 6 & 14.63 \\
\hline \multicolumn{3}{|l|}{ Cell arrangement } \\
\hline Dispersed & 37 & 90.24 \\
\hline Solid cluster & 16 & 39.02 \\
\hline Microfollicles & 16 & 39.02 \\
\hline Loosely cohesive & 15 & 36.58 \\
\hline Trabecular & 7 & 17.07 \\
\hline Rosettes & 3 & 7.31 \\
\hline Papillaroid & 2 & 4.87 \\
\hline Enmeshed in clots & 1 & 2.43 \\
\hline \multicolumn{3}{|l|}{ Binucleated and multinucleation } \\
\hline Present & 24 & 58.53 \\
\hline Absent & 17 & 41.46 \\
\hline \multicolumn{3}{|l|}{ Cell shape } \\
\hline Round to oval & 20 & 48.78 \\
\hline Spindle & 1 & 2.43 \\
\hline Both & 20 & 48.78 \\
\hline \multicolumn{3}{|l|}{ Cytoplasmic vacuoles } \\
\hline Present & 12 & 29.26 \\
\hline Absent & 29 & 70.73 \\
\hline \multicolumn{3}{|l|}{ Cytoplasmic granules } \\
\hline Present & 32 & 78.04 \\
\hline Absent & 9 & 21.95 \\
\hline \multicolumn{3}{|c|}{ Nuclear position in round to oval cells } \\
\hline Central & 19 & 46.34 \\
\hline Central to eccentric & 16 & 39.02 \\
\hline Eccentric & 5 & 12.91 \\
\hline Palisaded & 1 & 2.43 \\
\hline \multicolumn{3}{|l|}{ Nuclear overlapping } \\
\hline Present & 22 & 53.65 \\
\hline Absent & 19 & 46.34 \\
\hline \multicolumn{3}{|l|}{ Nuclear pleomorphism } \\
\hline Absent & 2 & 4.87 \\
\hline Mild & 22 & 53.65 \\
\hline Moderate & 13 & 31.70 \\
\hline Marked & 4 & 9.75 \\
\hline \multicolumn{3}{|l|}{ Nucleoli } \\
\hline Absent & 24 & 58.53 \\
\hline Occasional & 11 & 26.82 \\
\hline Few & 3 & 7.31 \\
\hline Many & 3 & 7.31 \\
\hline \multicolumn{3}{|l|}{ Nuclear inclusion } \\
\hline Present (occasional to few) & 4 & 9.75 \\
\hline \multicolumn{3}{|l|}{ Amyloid } \\
\hline Present & 15 & 36.58 \\
\hline Absent & 26 & 63.41 \\
\hline
\end{tabular}

In four cases (case no. 2, 3, 15 and 17), FNAC from only cervical lymph node was performed. Of these, in case no. 2 , thyroidectomy was done after suggestion of MTC on FNAC of cervical lymph node, while case no. 3 presented with thyroid and cervical lymph node swellings. Cervical lymph node FNAC was reported elsewhere as poorly differentiated metastatic carcinoma from thyroid. Preoperative serum calcitonin level was elevated. He underwent thyroidectomy in our institute and developed recurrent cervical lymph node enlargement from where FNAC was performed.

Case no. 15 was diagnosed outside as metastatic MTC cervical lymph node. Contrast-enhanced computerized tomography showed thyroid mass with bilateral cervical lymph node enlargement. Serum calcitonin and CEA levels were elevated. Patient was advised radiotherapy after thyroidectomy in our institute, but he was lost to follow-up. After 1 year, he presented with severe bone pain, lymph node swelling, and chest wall nodule. Bone scan showed multiple bone metastases. The FNA from cervical lymph node swelling (recurrent) as well as from the chest nodule was performed.

Case no. 17 was a diagnosed case of MTC elsewhere and presented with cervical lymph node swelling in our institute.

\section{Cytological Diagnosis Details}

Thirty-three specimens (80.48\%) had been suggested/ diagnosed as MTC or metastatic MTC on cytology. Although malignant cells were positive in two specimens (specimen nos 20 and 25), the exact tumor typing could not be made. In another case (specimen no. 4) of cervical lymph node aspiration, the differential diagnosis of paraganglioma and MTC was made. Two specimens (specimen nos. 1 and 2) were misdiagnosed as poorly differentiated carcinoma (PDC) of thyroid. The PDC was considered in the differential diagnosis along with MTC in one specimen (specimen no. 30). In another specimen (specimen no. 11), the differential diagnosis of MTC along with follicular neoplasm was made. Another specimen (specimen no. 41) was misinterpreted as follicular neoplasm. Malignant cells were absent in FNA of one specimen of cervical lymph node (specimen no 12), but on carefully reviewing the slides, few atypical cells having characteristic morphology seen in MTC were noted.

\section{Cytomorphological Features}

- Smear pattern/cell arrangement: In 26 specimens (63\%), the smears were moderately cellular (Fig. 1A). All specimens displayed mixed proportion of various cells in different arrangements (Fig. 1B). The most common cell arrangement (seen in $90 \%$ of specimens) was dispersed cell population (Fig. 1C), followed by solid clusters and microfollicular pattern, 39\% each (Table 2). In two cases, the microfollicular pattern 


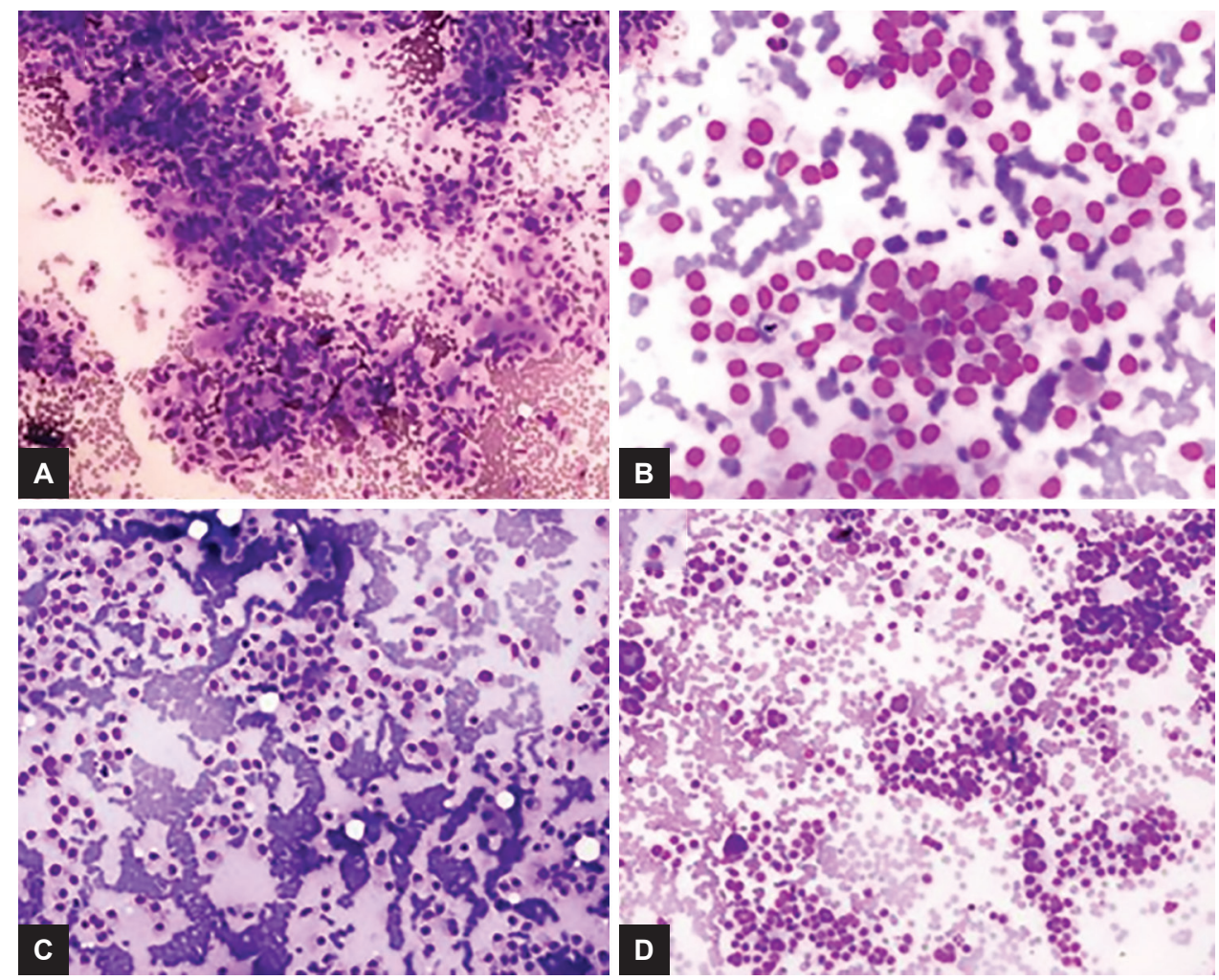

Figs 1A to D: Fine-needle aspiration of thyroid showing (A) moderately cellular smear (MGG stain $\times 40$ ), (B) loosely cohesive and dispersed cell population (MGG stain $\times 200$ ), (C) dispersed cell population (MGG stain $\times 200$ ), (D) tumor cells forming microfollicular pattern (MGG stain $\times 40$ )

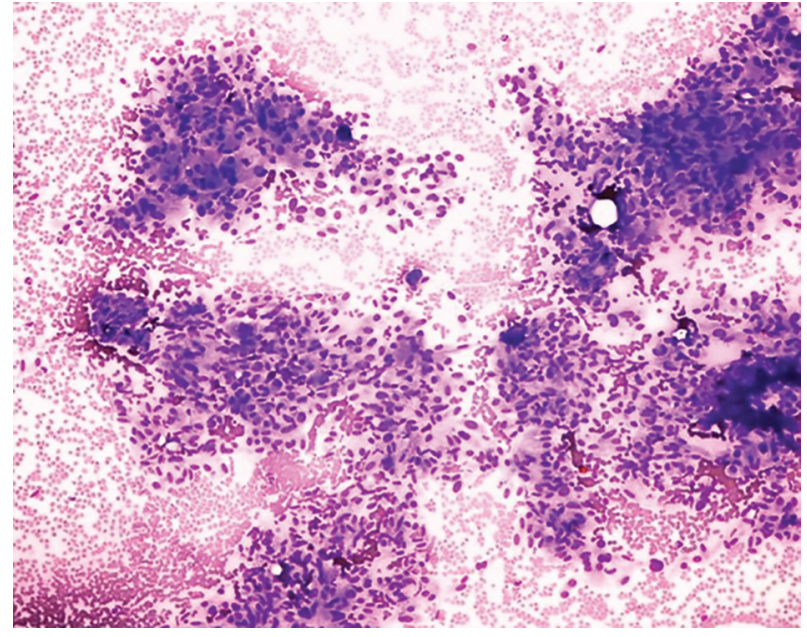

Fig. 2: Smear showing both type of cells, i.e., round to polygonal and spindle cells (MGG stain $\times 40$ )

predominated, so differential of follicular carcinoma was considered (Fig. 1D). Trabecular, papillaroid, and rosetting were also observed but they were focally present. One of the smears was predominantly hemorrhagic and atypical cells were enmeshed in clot.

- Cell types: Mixed cell population disposed in varying proportions of round to oval, and spindle cells were observed in large number of cases (Fig. 2). Almost half of the specimens (49\%) had round to oval (polygonal cells). Equal number of specimens (49\%) had both

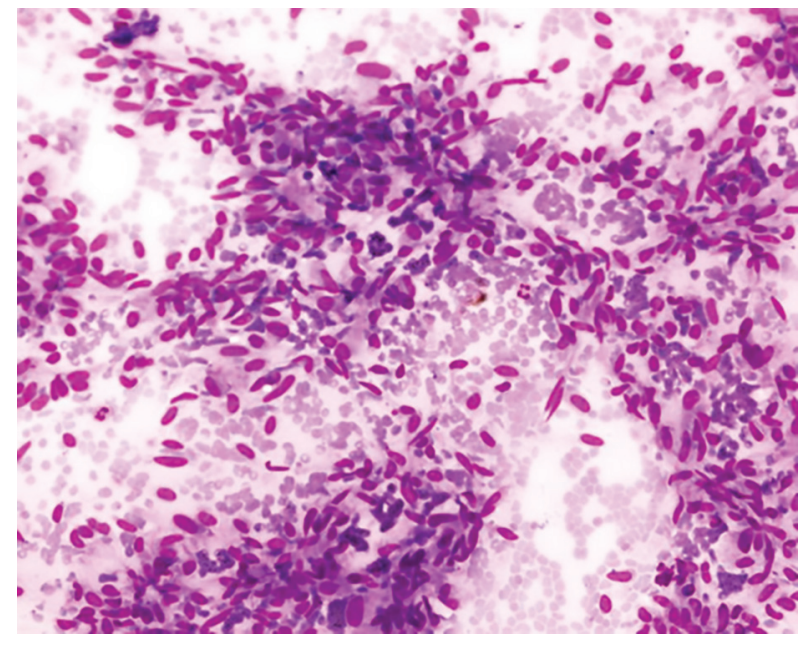

Fig. 3: Fine-needle aspiration smears showing predominantly spindle cells (MGG stain $\times 200$ )

round to oval and spindle cells. Remaining $2 \%$ of specimens had predominant spindle cells along with occasional polygonal cells (Fig. 3). Presence of bi- or multinucleated cells was also identified, although its number varied from occasional to many, but not the predominant (Fig. 4). Occasional bizarre cells were identified in only one specimen.

- Cytoplasmic features: Most of the specimens had moderate-to-abundant amount of cytoplasm in round to oval cells. Fine red cytoplasmic granules were 


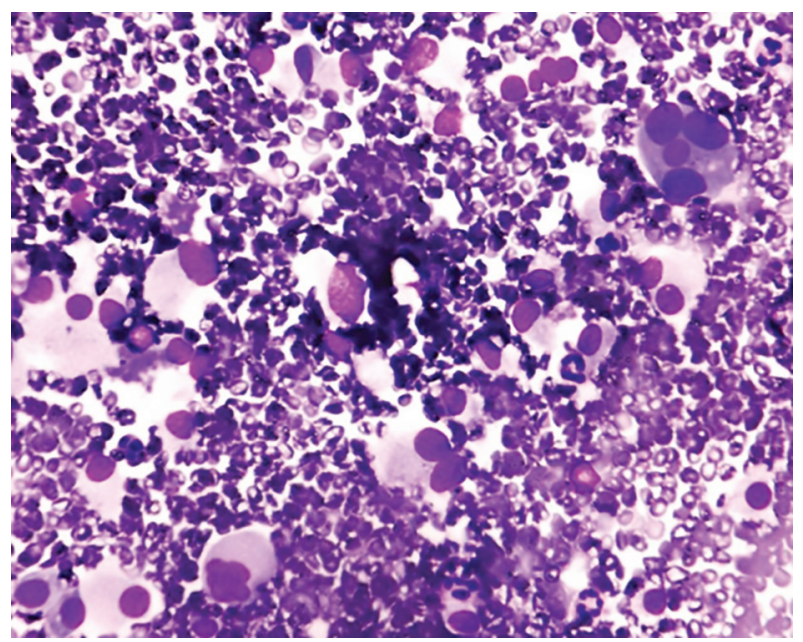

Fig. 4: Smear shows binucleated and multinucleated tumor cells (MGG stain $\times 400$ )

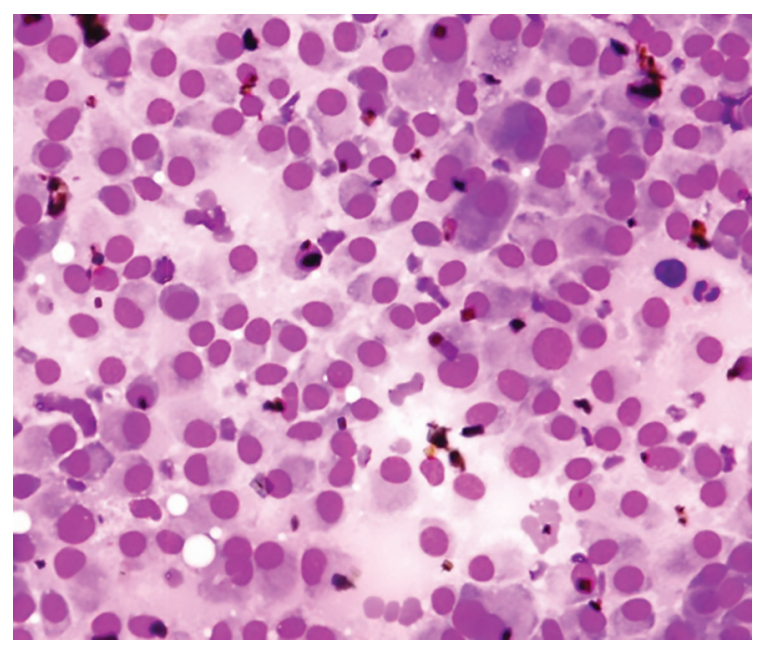

Fig. 6: Smear showing dispersed population of round to oval tumor cells displaying stippled chromatin, inconspicuous nucleoli, moderate amount of granular cytoplasm, and the nucleus is peripherally pushed giving plasmacytoid appearance (MGG stain ×400)

demonstrable in MGG stain in $78 \%$ of the specimens. Cytoplasmic vacuoles present in occasional to few cells were identified in $29 \%$ of the specimens (Fig. 5).

- Nuclear features: Apart from cell shape, the centric or eccentric (plasmacytoid) position of the nuclei varied in round to oval cells; $46 \%$ of the specimens had centrally placed nuclei, while in $39 \%$ of specimens, many cells had both central and plasmacytoid morphology. Predominant plasmacytoid cells were noted in 13\% of specimens (Fig. 6). Occasional to few palisaded cells were identified in only one specimen. Almost all the specimens (except two specimens) had mildto-moderate nuclear pleomorphism (Fig. 7). Of these, approximately half of the specimens (54\%) showed mild nuclear pleomorphism. Presence of nucleoli was not frequent and observed occasionally in $22 \%$. Nuclear overlapping was seen in few groups or

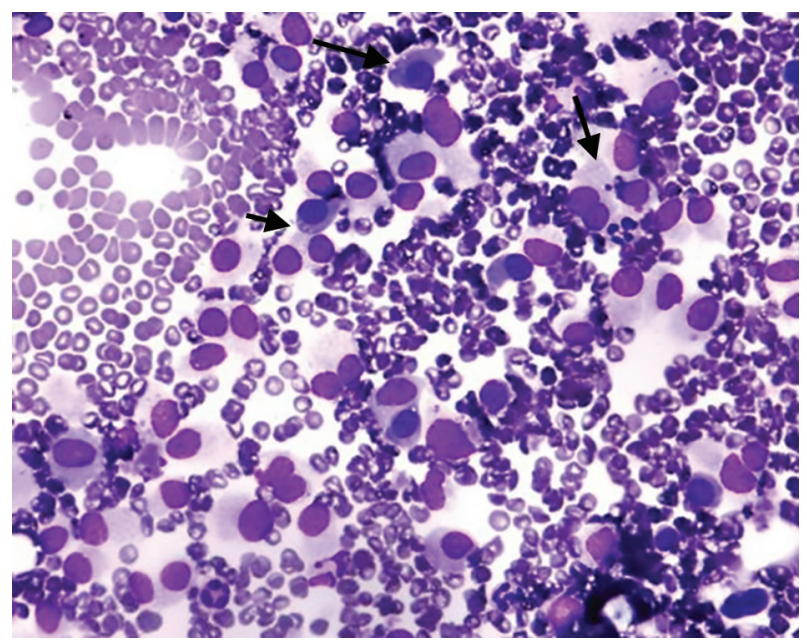

Fig. 5: Smear showing plasmacytoid tumor cells having round to oval cells displaying stippled chromatin, inconspicuous nucleoli, moderate amount of granular cytoplasm showing fine vacuolation (arrow) (MGG stain $\times 400$ )

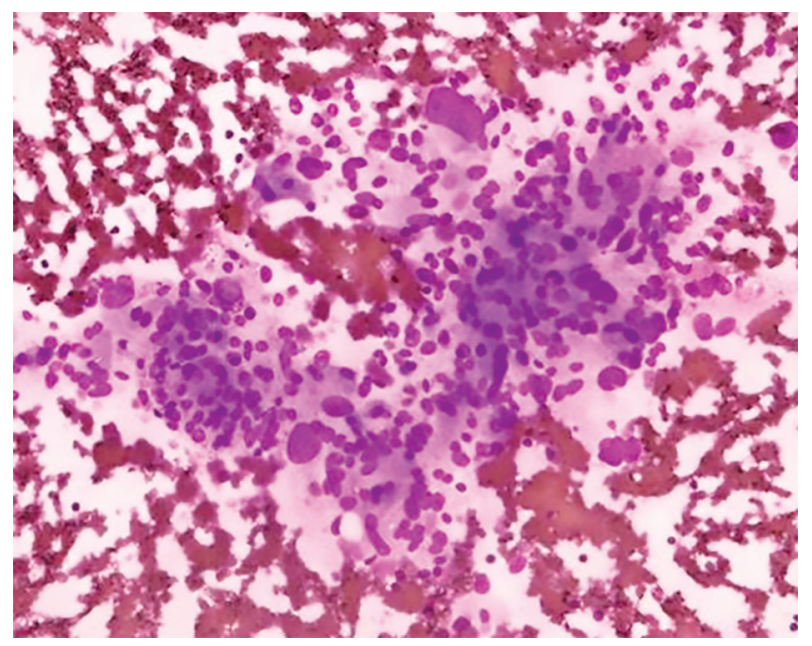

Fig. 7: Smear showing tumor cells disposed in cohesive clusters displaying abrupt moderate degree of pleomorphism and nuclear overlapping (MGG stain $\times 400$ )

clusters in $54 \%$ of specimens. Ten percent of the specimens had nuclear inclusion in only occasional to few cells. Mitosis was not seen in any of the specimens. All of the specimens showed fine granular chromatin, a feature of neuroendocrine tumor and better appreciated in Pap smear.

Most of the specimens on retrospectively reviewing showed amyloid as extracellular flecks or aggregates of amorphous deposits, which was pink or gray in color on MGG in the background (Fig. 8). It was found in $37 \%$ of specimens.

\section{Case Confirmation}

Subsequent to cytology, histopathological confirmation by surgery was performed in 25 cases (Fig. 9). On immunohistochemistry, tumor cells were positive for chromogranin, neuron-specific enolase, and cytokeratin. One case (case 


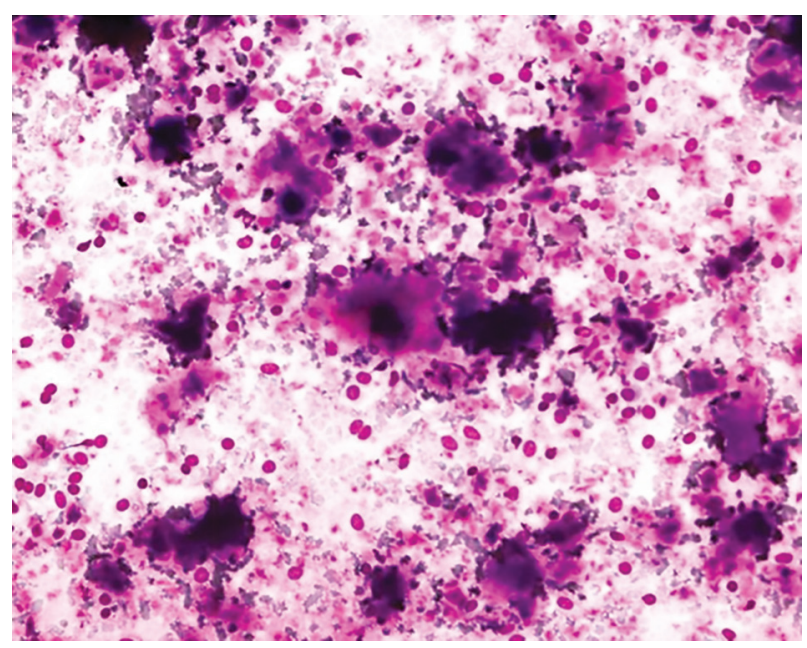

Fig. 8: Fine-needle aspiration smear from the thyroid displaying abundant amount of amorphous pink to violet amyloid (MGG stain $\times 400$ )

no. 20) refused thyroidectomy because of personal reasons; however, she was genetically confirmed to have MEN 2A syndrome. Congophilic deposits showed apple green birefringence under polarized light on FNA of thyroid and later, the patient was lost to follow-up (case no. 19). Another case (case no. 17) was diagnosed elsewhere as MTC and presented with substernal lymph node swelling.

\section{DISCUSSION}

The MTC is a rare malignant tumor of thyroid gland showing C-cell differentiation. It constitutes 5 to $10 \%$ of all the thyroid malignancy. Table 3 summarizes the reported series of MTC available in the literature. Up to $25 \%$ of these tumors are inheritable, caused by gain-of-function germline mutation in the RET proto-oncogene. Sporadic specimens account for about $80 \%$ of the specimens presenting as unilateral masses in middle-aged women, with mean age of presentation of 50 years. ${ }^{3}$ In the present study, the age ranged from 9 to 75 years with a mean age of 45.3 years. Further screening by appropriate investigations including genetic analysis for associated syndromes could not be made in all of our cases due to financial constraints. However, one family was screened and found to have MTC on cytology in three siblings, i.e., two daughters and one son (Case no. 20-23). On subsequent investigations, it turned out to be MEN 2A. Case no. 20 did not undergo thyroid surgery due to personal reasons.

The MTC is more common in females. However, the present study showed a male preponderance, possibly related to gender differences in hospitalization in our country. Similarly, male predominance was also shown in other studies. ${ }^{4,5}$

The exact etiology of sporadic MTC is unknown. Rarely, it may arise in the setting of Hashimoto's disease, but this may be a coincidental finding.

Patients with MTC may present with a thyroid mass and variable symptoms related to the production of amine precursors, including calcitonin. They invariably demonstrate an elevated serum calcitonin. 6,7

Cytomorphological features of MTC although are well defined may show a variable picture that can mimic both primary and metastatic lesions of the thyroid gland and give rise to diagnostic problems.

Almost all of the aspirates in the present study had typical features of MTC like polygonal cells along with plasmacytoid cells and spindle cells in various proportions in a background of dispersed atypical cells.

Thirty-three specimens (80\%) had been suggested/ diagnosed as MTC (or metastatic MTC) on cytology. On reviewing the literature (Table 3), the accuracy of MTC
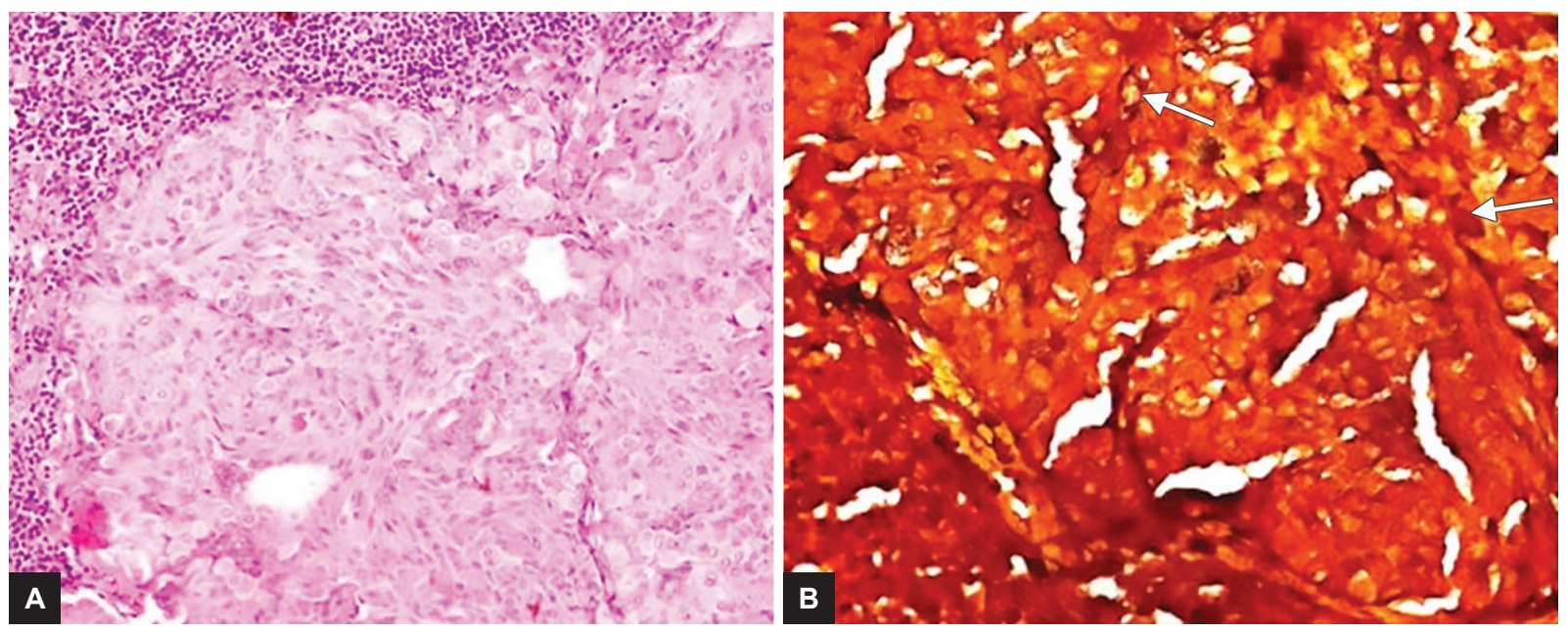

Figs 9A and B: Histopathology of cervical lymph node. (A) H\&E-stained sections show tumor cells disposed in solid nests having round to oval, regular nuclei with coarse chromatin and moderate amount of granular cytoplasm. At the periphery, thin rim of mature lymphoid cells are seen (H\&E stain $\times 200)$. (B) Tumor cells showing Grimelius positivity as dark granules at the periphery of the cytoplasm of the tumor cells (arrow) (Grimelius stain $\times 200$ ). H\&E: Hematoxylin and eosin 


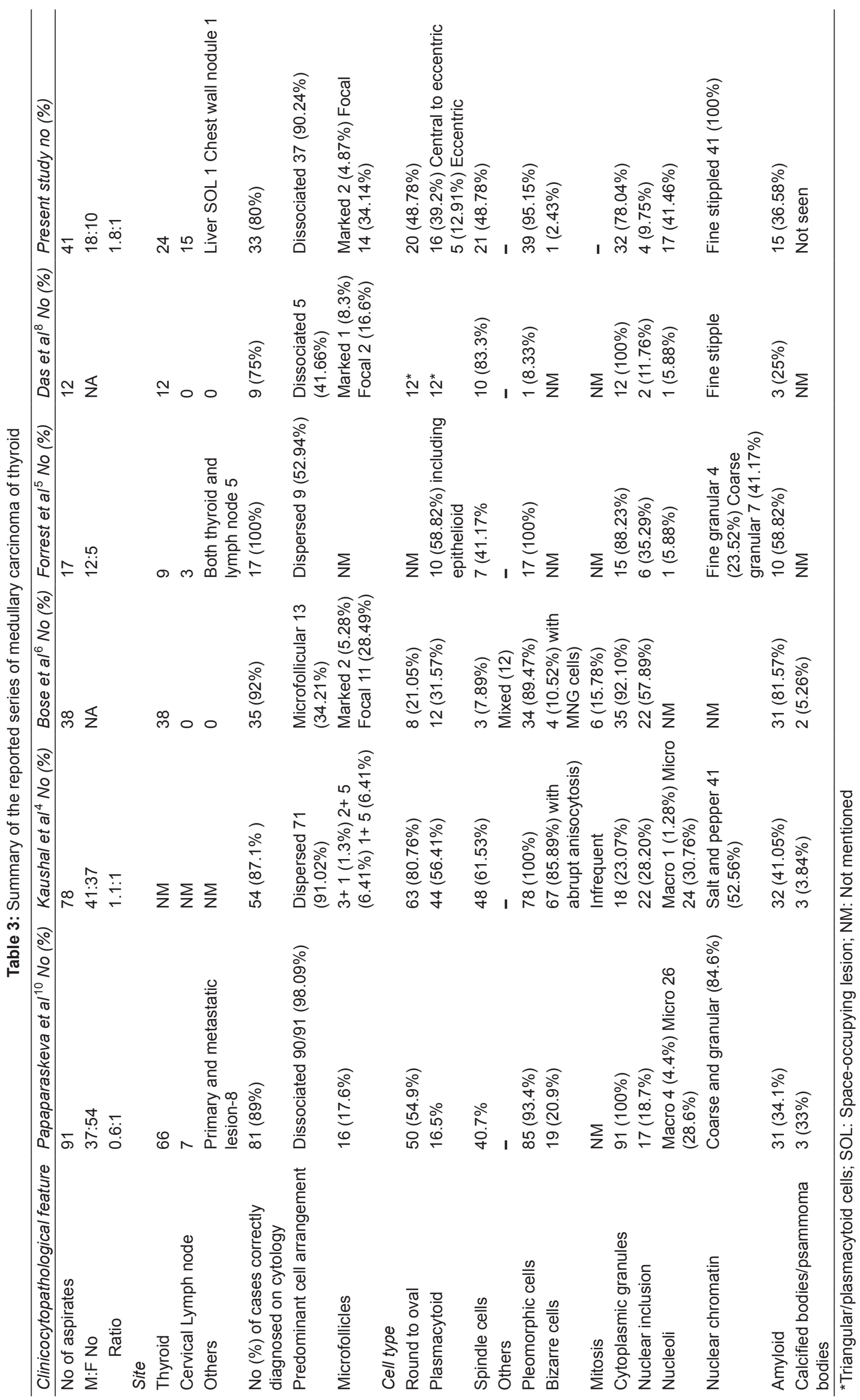


on cytology varied from 75 to $100 \% .5,8$ In a study by Kaushal et al ${ }^{4}$ definite cytological diagnosis of medullary carcinoma was made in $87.1 \%$ of aspirates based on cytomorphology alone, and it was $12.9 \%$ based on immunocytochemistry for calcitonin. In a study of 38 cases by Bose et al, ${ }^{6} 35$ cases (92\%) were correctly diagnosed on cytology. Malignant cells were positive in two of our specimens (specimen nos. 20 and 25), but the exact tumor typing could not be made. These specimens were from the chest wall nodule and thyroid. Low cellularity in both of these cases might be the cause of not typing it under specific tumor. The patient who presented with chest wall nodule was an operated case of thyroidectomy. Subsequent to surgery, he was advised radiotherapy, but he was lost to follow-up. Later on, he again presented with severe bone pain and chest wall nodule. Bone scan showed multiple bone metastases. The FNA from the chest nodule revealed few atypical cells entrapped in the blood clot. This might be the reason for guarded reporting in this case.

The most significant finding that was constantly and uniformly noted in the present study was fine stippled nuclear chromatin, i.e., it was appreciated in all of the specimens (100\%). Similar finding was shown by Das et al. ${ }^{8}$ The other useful finding in the present study was nuclear pleomorphism $(95 \%)$ that ranged from mildto-moderate and was best seen in clusters as an abrupt anisonucleosis. Multinucleated giant cells, along with bizarre cells with abrupt anisonucleosis were seen more likely in MTC apart from anaplastic carcinoma. ${ }^{4}$

Most frequently, the aspirates were moderate-to-high cellular depending on the degree of stromal fibrosis and amyloid deposition. ${ }^{9}$ Moderate cellular smears were seen in $63 \%$ of specimens, low cellular in $15 \%$ of specimens, and high cellular in $22 \%$ of specimens in this study. Cell fragments described in MTC were mainly poorly cohesive often with dispersed pattern. There is a tendency of the tumor cells for cell dispersion.

Another important feature of this study was dispersed cell arrangement (90.24\%). Papaparaskeva et $\mathrm{al}^{10}$ had described dissociated cells in $90 \%$ of specimens. Similar findings were also described in other studies. ${ }^{4,5,8,11}$

Apart from dissociated cells, MTC may be disposed in different patterns, i.e., solid, rosettes, trabeculae, follicular, and papillary. ${ }^{11}$ In the present study, solid clusters as well as microfollicular pattern were seen in 39\% each. Two of our specimens (i.e., specimen nos. 11 and 41) showed many microfollicles that misled us for the diagnosis of follicular neoplasm. Microfollicular arrangement is not infrequent finding in MTC. In two studies, follicular neoplasm was misdiagnosed in 5.5 and $8 \%$ of cases, but at the same time, the eccentric location of the nucleus, salt and pepper chromatin, moderate amount of the granular cytoplasm, and bi- and multinucleated cells suggested the possibility of MTC. ${ }^{8,10}$ Other clue that we should look for is the presence of amyloid staining gray green on the Pap stain, seen in the center of the follicles as well as spindling and dispersed cells. This type of microfollicular pattern may be seen in follicular variant of the MTC. Hence, it is not only the cellular pattern but a careful look at nuclear and cytoplasmic character as well as search for the amyloid may clinch a diagnosis. Focal papillary fragments have also been described in the literature. ${ }^{10}$ In our study, although occasional papillaroid fragments were seen, the nuclear features characteristic of papillary carcinoma were not evident. The papillaroid fragment may be due to surviving cells around the vessels and cells away from the central vessel not getting blood supply and falling off.

Types of cells that can be seen in MTC are round to ovoid or polygonal and spindle cells. The presence of mixed cell population is a diagnostic pointer to MTC and is described by few authors, but if one cell type predominates, i.e., round to polygonal with eccentric cytoplasm, i.e., plasmacytoid appearance, it also gives the clue for the diagnosis of MTC, especially the oncocytic variant of MTC. ${ }^{6,8}$ Similar cells with eccentric nucleus are also seen in Askanazy cells and among the neoplasm in Hurthle cell neoplasm, lymphoma, and melanoma. The cytoplasm, however, is less dense and does not have prominent nucleoli unlike seen in the Hurthle cells (Fig. 10). Moreover, the granules which are often present in Askanazy cells are violet in contrast to red granules of MTC. Lymphoma has a different chromatin pattern. Melanoma would have frequent macronucleoli and mitosis. In the present study, cells showing only eccentric nuclei were seen in $13 \%$ of specimens. Prominent nucleoli are not a feature of MTC, and if it is seen, it is not present in all cells. It was seen in many cells in only one of our specimens. Furthermore, the round to polygonal cells and spindle cells are also seen in melanoma, but it has macronucleoli, mitosis, and necrosis and all of these are not characteristically seen in MTC. Pure spindle cell MTC has been reported only in a small number of series. In a series of 31 specimens, $45 \%$ of MTC were of pure spindle cell MTC.12 In the current series, predominant spindle cells were seen in only $2 \%$ of specimens. The nucleus in these spindle cells was more central and the cytoplasm was less distinct. Some spindle cell tumors have a distinctly mesenchymal appearance. ${ }^{13}$ Schwannoma/neurofibroma, spindle cell melanoma come in differential diagnosis of spindle cell morphology.

Many binucleated and multinucleated cells, nuclear pleomorphism, and bizarre cells may be seen in MTC, especially in giant cell variant of MTC. Our study also 


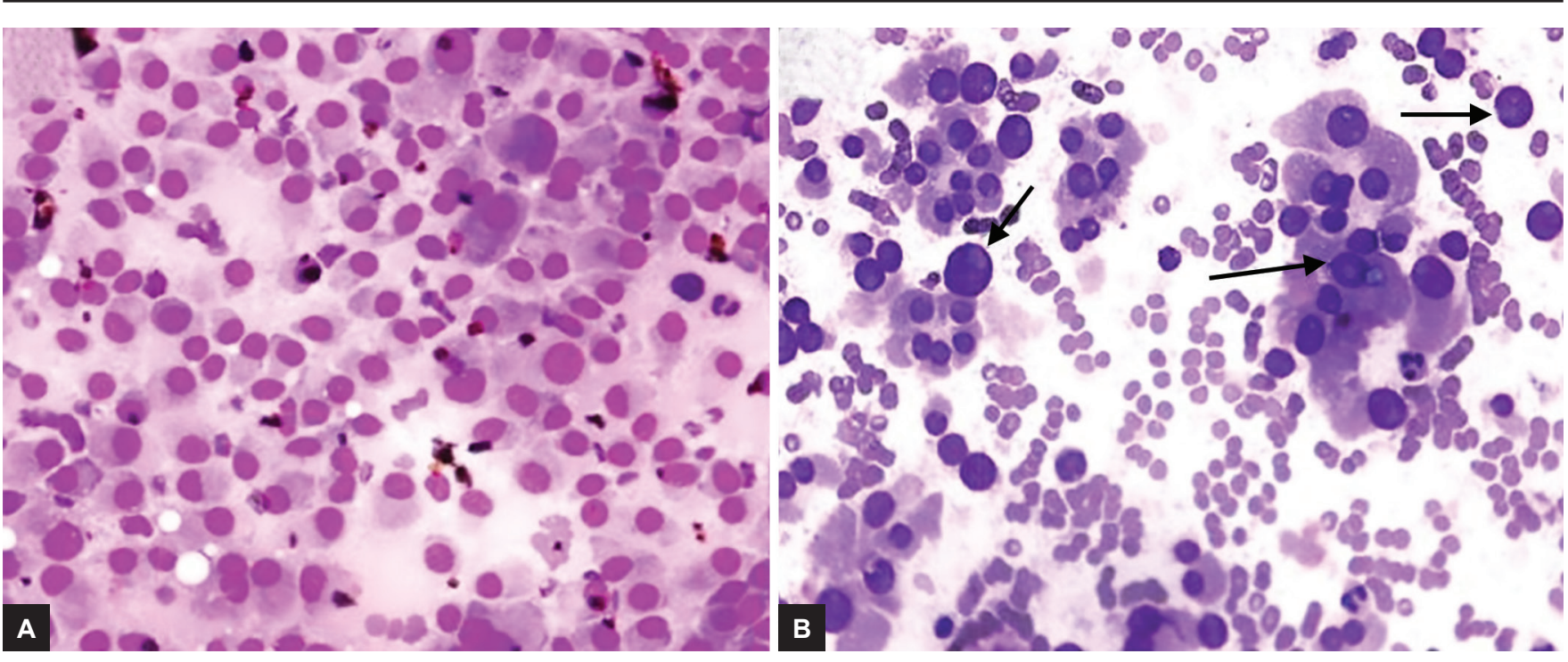

Figs 10A and B: Comparison of tumor cells of MTC and Hurthle cell neoplasm. (A) Cells of MTC have inconspicuous nucleoli. (B) Tumor cells of Hurthle cell neoplasm too have plasmacytoid round to oval cells but typically have dense cytoplasm and prominent nucleolus unlike the MTC (MGG stain ×400)

had binucleated as well as multinucleated cells $(59 \%$ of specimens), but they did not constitute the major cells. Only occasional few bizarre cells were appreciated in one specimen. The presence of bizarre giant cells, necrosis, spindle cells particularly in elderly patient prompts us to make a diagnosis of anaplastic carcinoma but unlike MTC, clinically it presents as hard rapidly enlarging mass and has moderate pleomorphism in tumor cells as well as multiple nucleoli along with coarse and clumped chromatin. But in the giant cell variant of MTC, careful attention to the pleomorphism of polygonal cells and spindle cells in the background helps in achieving the diagnosis of giant cell variant of MTC. ${ }^{4}$

In MTC, the cytoplasm is moderately dense and has a fairly well-defined cytoplasmic border, sometimes described as triangular-shaped. ${ }^{14}$ Cytoplasmic granularity is usually fine and may not be seen in all the cells. It was found in $78 \%$ of our specimens. Its presence ranged from 23 to $100 \%$ of specimens in different studies. ${ }^{4,5,8,10}$ Multinucleated cells more often show these features as compared with scattered cells. It should be kept in mind that while these granules are invisible in alcohol-fixed Pap-stained smears, they show typically fine pink, cytoplasmic granularity on MGG staining. This granularity is a helpful diagnostic feature, but is also observed in some of the follicular carcinoma and in some anaplastic carcinoma. ${ }^{11,15}$

The current study had total of three specimens having diagnosis of PDC (one had differential diagnosis of MTC and PDC, and the other two were wrongly diagnosed as PDC). It might be because of cellular arrangement, i.e., trabecular solid or cohesive cluster as well as nuclear pleomorphism, occasional dispersed cells showing central to round nuclei and spindle cells. Smears from MTC with solid sheets of tumor cells without discohesion are more often difficult to distinguish from PDC. The nuclear as well as cytoplasmic details are not only of the predominant cell clusters but also of the background cell. Even if they are present occasionally, it is important to be seen to arrive at a proper diagnosis. Like in these specimens, on carefully reviewing the slides, the characteristic neuroendocrine type stippled chromatin was seen in both of these specimens. Cytoplasmic vacuoles and granules can also be appreciated. The most predictive characteristic cytomorphological findings of PDC according to one study are severe crowding, insular/solid/trabecular pattern, single cells and high nuclear/cytoplasmic ratio. ${ }^{16}$ None of these specimens in our study had high nuclear/ cytoplasm ratio.

Malignant cells were absent in one of the aspirates from cervical lymph node, but on reviewing the slides, few atypical cells were characteristically seen in MTC. In smears, amyloid appears as amorphous clumps or fibrillary which stain variable shades of pink or violet with MGG and is organophilic with Pap staining. ${ }^{17}$ Occasionally, it may appear as discrete blobs surrounded by tumor cells, giving a follicular pattern. It may be confused with colloid or small amount of stromal or connective fragments and may be absent in up to $50 \%$ of the specimens. In present study, it was demonstrable in only $37 \%$ of specimens, while in different studies, it ranged from 25 to $81 \% .{ }^{6,8}$ Tumor necrosis and mitosis can be seen in large-sized tumors. Two of our specimens were misdiagnosed as PDC, and it may be because of the necrosis. Rarely, fragments of calcification or psammoma bodies may be seen. 
Up to $50 \%$ of the patients may present with nodal metastasis and up to $15 \%$ may have distant metastasis involving regional and mediastinal lymph nodes. ${ }^{3}$ In this present study, cervical lymph node was involved in 15 specimens. In one case of cervical lymph node aspiration, the differential diagnosis of paraganglioma (again the status of thyroid was overlooked) and MTC was made. So, it is always important to clinically examine the thyroid in case of cervical lymph node aspiration as well as to do the FNAC from the same, if needed. Kaushal et $\mathrm{al}^{4}$ had described paraganglionic-like variant of MTC where cytology showed cohesive syncytial fragments with ill-defined margins and nuclear features like oval shape and focal spindling and subsequently made them think of MTC on MGG-stained smears.

These tumors have the tendency toward extra-thyroid extension and involvement of the contralateral lobe. The commonest sites for distant metastasis include lung, bone, liver, and adrenal.

The gold standard for the diagnosis of MTC is immunostain for calcitonin. Calcitonin stains both the tumor cells and the amyloid. However, in some specimens of our study, due to scant material, it may not be feasible. In such specimens, it is prudent to recommend serum calcitonin levels to establish the diagnosis of MTC. Calcitoninnegative MTC has also been reported in the literature, but these tumors usually occur in the familial setting or are associated with C-cell hyperplasia. ${ }^{18}$

\section{CONCLUSION}

It is advantageous to diagnose MTC preoperatively, as this tumor may be a familial or a part of associated MEN syndrome. Ultrasound-guided FNAC is a fairly accurate, relatively safe, rapid, and simple tool to diagnose, and has emerged as the preferred method not only for preoperative diagnosis, but also for the subsequent suspicion of other associated lesion in the same person or in the family member. Although the cytological features of MTC are well described, different patterns may pose a diagnostic difficulty. The pathologist should be well aware of the mimics of the MTC. Early diagnosis and treatment would lead to a markedly improved cure rate of these neoplasms.

\section{REFERENCES}

1. Horn RC Jr. Carcinoma of the thyroid. Cancer 1951 Jul;4(4): 697-707.

2. Hazard JB, Hawk WA, Crile G Jr. Medullary (solid) carcinoma of the thyroid: a clincopathological entity. J Clin Endocrinol Metab 1959 Jan;19(1):152-161.
3. Matias-Guiu, X.; DeLellis, R.; Moley, JF. Medullary thyroid carcinoma. In: DeLellis RA, Lloyd RV, Heitz PU, Eng C, editors. Pathology and genetics of tumours of the endocrine organs. World Health Organization Classification of Tumours. Lyon: IARC Press; 2004. pp. 85-91.

4. Kaushal S, Iyer VK, Mathur SR, Ray R. Fine needle aspiration cytology of medullary carcinoma of the thyroid with a focus on rare variants: a review of 78 cases. Cytopathol 2010 Apr;22(2):95-105.

5. Forrest CH, Frost FA, de Boer WB, Spagnolo DV, Whitaker D, Sterrett BF. Medullary carcinoma of the thyroid: accuracy of diagnosis of fine needle aspiration cytology. Cancer 1998 Oct;84(5):295-302.

6. Bose S, Kapila K, Verma K. Medullary carcinoma of the thyroid: a cytological, immunocytochemical and ultra structural study. Diagn Cytopathol 1992 Jan;8(1):28-32.

7. Collins BT, Cramer HM, Tabatowski K, Hearn S, Raminhos A, Lampe H. Fine needle aspiration of medullary carcinoma thyroid: cytomorphology immunocytochemistry and electron microscopy. Acta Cytol 1995 Sep;39(5):920-930.

8. Das A, Gupta SK, Banerjee AK, Srinivasan R, Radotra BD, Nijhawan R, Dey P, Rajwanshi A. Atypical cytologic features of medullary carcinoma of the thyroid. A review of 12 cases. Acta Cytol 1992 Mar-Apr;36(2):137-141.

9. Gray, W.; McKee, GT.; Buley, ID. The thyroid gland. In: Gray W, McKee GT, editors. Diagnostic cytopathology. 2nd ed. New York: Churchill Livingstone; 1995. pp. 576-577.

10. Papaparaskeva K, Nagel H, Droese M. Cytological diagnosis of medullary carcinoma of the thyroid gland. Diagn Cytopathol 1999 Jun;22(6):351-358.

11. Ljungberg O. Cytological diagnosis of medullary carcinoma of the thyroid gland with special regard to the demonstration of amyloid in smears of fine needle aspirates. Acta Cytol 1972 May-Jun;16(3):253-255.

12. Mendonca ME, Ramos S, Soares J. Medullary carcinoma of thyroid: a re- evaluation of the cytological criteria of diagnosis. Cytopathology 1991 Apr;2(2):93-102.

13. Blonk DI, Talerman A, Vissar-van Dijk MN. The cytology of medullary carcinoma the thyroid with spindle cell pattern. Arch Geschwulstforsch 1978;48(4):313-317.

14. Soderstrom N, Telenius-Berg M, Akerman M. Diagnosis of medullary carcinoma of the thyroid by fine needle aspiration biopsy. Acta Med Scand 1975 Jan-Feb;197(1-2):71-76.

15. Lowhagen T, Sprenger E. Cytological presentation of thyroid tumours in aspiration biopsy smear. Acta Cytol 1974 MayJun;18(3):192-197.

16. Bongiovanni M, Bloom L, Krane JF, Baloch ZW, Powers CN, Hintermann S, Pache JC, Faquin WC. Cytomorphological features of poorly differentiated thyroid carcinoma: a multiinstitutional analysis of 40 cases. Cancer 2009 Jun;117(3): 185-194.

17. Orell, SR.; Sterret, GF.; Walters, MN.; Whitaker, D. The thyroid gland. In: Orell SR, editor. Manual and atlas of fine needle aspiration cytology. 2nd ed. Edinburg: Churchill Livingstone, Longman Group, UK Limited; 1992. pp. 119-125.

18. Schmid KW, Ensinger C. "Atypical" medullary thyroid carcinoma with little or no calcitonin expression. Virchows Arch 1998 Sep;433(3):209-215. 